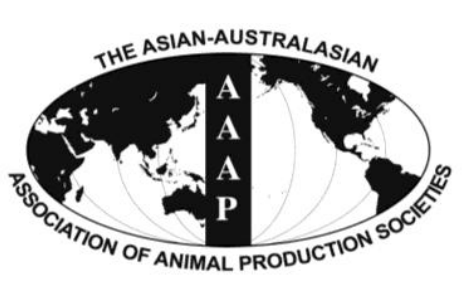

Open Access

Asian Australas. J. Anim. Sci.

Vol. 27, No. 2 : 209-216 February 2014

http://dx.doi.org/10.5713/ajas.2013.13243

www.ajas.info

pISSN 101 1-2367 elSSN 1976-5517

\title{
The Net Energy Values of Corn, Dried Distillers Grains with Solubles and Wheat Bran for Laying Hens Using Indirect Calorimetry Method
}

\author{
D. Ning, J. M. Yuan, Y. W. Wang, Y. Z. Peng, and Y. M. Guo* \\ State Key lab of Animal Nutrition, College of Animal Science and Technology, \\ China Agricultural University, Beijing, 100193, China
}

\begin{abstract}
The present study was conducted to estimate the NE values of corn, dried distillers grains with solubles (DDGS) and wheat bran (WB) for laying hens based on an indirect calorimetry method and nitrogen balance measurements. A total of 576 twentyeight-wk-old Dwarf Pink-shell laying hens were randomly assigned to four groups fed a basal diet (BD) or a combination of BD with $50 \%$ corn or $20 \%$ DDGS or $20 \% \mathrm{WB}$, with four replicates each. After a 7-d adaptation period, each replicate with 36 hens were kept in one of the two respiration chambers to measure the heat production (HP) for 6 days during the feeding period and subsequent 3-d fasting. The equilibrium fasting HP (FHP) provided an estimate of NE requirements for maintenance (NEm). The NE values of test feedstuffs was estimated using the difference method. Results showed that the heat increment that contributed 35.34 to $37.85 \%$ of $\mathrm{ME}$ intake was not influenced by experimental diets ( $>>0.05$ ) when expressed as Mcal $/ \mathrm{kg}$ of DM feed intake. Lighting increased the HP in hens in an fed-state. The FHP decreased over time $(\mathrm{p}<0.05)$ with the lowest value determined on the third day of starvation. No significant difference between treatments was found on FHP of d 3 (p>0.05). The estimated AME, AMEn, and NE values were 3.46, 3.44 and $2.25 \mathrm{Mcal} / \mathrm{kg} \mathrm{DM}$ for corn, 3.11, 2.79, and 1.80 Mcal $/ \mathrm{kg} \mathrm{DM}$ for DDGS, 2.14, 2.10, and 1.14 Mcal $/ \mathrm{kg} \mathrm{DM}$ for WB, respectively. The net availability of AME of corn tended to be numerically higher than DDGS and WB ( $p=0.096$ ). In conclusion, compared with corn, the energy values of DDGS and WB were overestimated when expressed on an AME basis. (Key Words: Corn, Dried Distillers Grains with Solubles, Indirect Calorimetry, Laying Hens, Net Energy, Wheat Bran)
\end{abstract}

\section{INTRODUCTION}

As the energy accounts for the greatest proportion of feed costs, an accurate estimate of the energy value of raw materials is extremely important for reducing the cost of poultry feed. Evaluation of energy content of poultry feeds is usually based on ME value (NRC, 1994). The NE system, which allows the heat increment (HI) of feeding to be calculated, theoretically provides an energy value closest to the "true" energy value of the feed (Noblet et al., 1994a, b).

In the past several years (Noblet et al., 1994a) interest has increased in predicting NE values of feeds for pigs based on their digestible nutrient levels or from $\mathrm{DE}$ or $\mathrm{ME}$ and chemical characteristics or from chemical composition.

*Corresponding Author: Yuming Guo. Tel: +86-10-62733900, Fax: +86-10-62733900, E-mail: guoyum@ cau.edu.cn

Submitted May 3, 2013; Accepted Jul. 12, 2013; Revised Aug. 23, 2013
However, the objective of NE system cannot be achieved completely because NE equations make no allowance for variation in such factors as body weight or physiological state of an animal and so on (Birkett and de Lange, 2001b). This leads to limited use of different NE values for the same ingredient depending on the type of production (i.e. for maintenance only, or for growth).

An indirect calorimetry technique was frequently used to measure dietary NE values. Based on tube feeding, Sarmiento-Franco et al. (2000) using an indirect calorimetry method found that lighting schedules may indirectly affect the estimated NE values of two high fiber feedstuffs in cockerels. A factorial analysis procedure was usually used to estimate $\mathrm{NE}$ values of diets that combines $\mathrm{NE}$ for maintenance (NEm) and production (Noblet et al., 1994a, b). However, NEm is difficult to measure directly, the equilibrium fasting heat production (FHP) is frequently used to estimate NEm (Birkett and de Lange, 2001a, b). But 
it is difficult to assess how long hens should be fasted when calculating the FHP. Li et al. (1991) found that the heat production (HP) associated with feeding in laying hens had disappeared after $22 \mathrm{~h}$ of fasting. However, the results of O'Neill and Jackson (1974) and Sakomura et al. (2005) showed that the variability between hens of different genotypes and the experimental methodology may influence the estimation of FHP.

A few NE values of feed ingredients for laying hens have been obtained experimentally (Wang et al., 2010b). The objective of the present study was to evaluate the energy values of corn, dried distillers grains with solubles (DDGS) and wheat bran (WB) and discuss the factors that affect the accuracy of estimated NE values for laying hens based on indirect calorimetry method. The NE values of test ingredients were estimated using the difference method according to their substitution ratio in the basal diet.

\section{MATERIALS AND METHODS}

\section{Raw materials}

For the corn, DDGS (Jilin Procince New Tian Long Wine Co.,Ltd., China) and wheat bran samples, the methods of AOAC (1990) were used for measuring dry matter (DM), crude protein (CP), and ether extract (EE). Neutral detergent fiber (NDF) and acid detergent fiber (ADF) were measured after amylolytic pretreatment according to the methods of Van Soest and Wine (1967). Gross energy (GE) content was measured with an adiabatic bomb calorimeter. The chemical composition and GE of the ingredients are shown in Table 1.

\section{Experimental design and diets}

The study protocol was approved and conducted in accordance with the Animal Ethics Committee guidelines of China Agricultural University.

A total of 576 twenty-eight-wk-old Dwarf Pink-shell laying hens (Dwarf brown $\times$ Leghorn) were selected at approximately $1.07 \pm 0.02 \mathrm{~kg}$ body weight $(\mathrm{BW})$ and randomly allocated into four dietary treatments with four replicates per treatment and 36 hens per replicate. The four

Table 1. Chemical composition and gross energy of corn, dried distillers grains with solubles (DDGS) and wheat bran (WB)

\begin{tabular}{|c|c|c|c|}
\hline Item & Corn & DDGS & WB \\
\hline $\mathrm{DM}(\%)$ & 89.12 & 91.87 & 90.55 \\
\hline $\mathrm{CP}(\%)$ & 8.42 & 27.81 & 18.82 \\
\hline $\mathrm{EE}^{1}(\%)$ & 3.99 & 8.84 & 5.86 \\
\hline NDF (\%) & 9.23 & 36.84 & 41.51 \\
\hline $\operatorname{ADF}(\%)$ & 2.45 & 10.21 & 12.46 \\
\hline Hemicellulose $^{2}(\%)$ & 6.78 & 26.63 & 29.05 \\
\hline GE (Mcal/kg) & 3.91 & 4.94 & 4.08 \\
\hline
\end{tabular}

\footnotetext{
${ }^{1} \mathrm{EE}=$ Ether extract.

${ }^{2}$ Estimated by subtraction of ADF from NDF.
}

experimental diets were basal diet (BD), basal diet substituted by $50 \%$ of corn (CBD), basal diet substituted by $20 \%$ of DDGS (DBD) and basal diet substituted by $20 \%$ of WB (WBD). Experimental periods for each replicate consisted of 7 days of adaptation to dietary treatments followed by indirect calorimetry and 7 days N-balance measurements in one of two open-circuit respiration chambers. An adaptation period of 7 days was chosen to adjust to the new experimental diet. Ingredients and nutrient composition of the basal diet are shown in Table 2.

\section{Indirect calorimetry and nitrogen balance measurements}

Each respiration chamber was equipped with two tiers of 12 metabolic cages $(39 \times 37 \times 40 \mathrm{~cm})$ each with three hens. Every three cages included one tray to collect the excreta of hens. The door of each respiration chamber contained a window that allowed for general observation of the birds.

Table 2. Composition and calculated nutrient levels of the basal $\operatorname{diet}(\mathrm{BD})$

\begin{tabular}{|c|c|}
\hline Ingredient (\%) & Basal diet \\
\hline Corn & 63.09 \\
\hline Soybean meal ${ }^{1}$ & 25.76 \\
\hline Limestone & 7.99 \\
\hline Dicalcium phosphate & 1.68 \\
\hline Vitamin premix ${ }^{2}$ & 0.02 \\
\hline Trace mineral premix ${ }^{3}$ & 0.2 \\
\hline DL-Methionine & 0.14 \\
\hline L-Threonine & 0.03 \\
\hline Maifan stone & 0.63 \\
\hline Choline chloride & 0.12 \\
\hline Salt & 0.30 \\
\hline Antioxidant & 0.03 \\
\hline Total & 100.00 \\
\hline \multicolumn{2}{|l|}{ Nutrients levels } \\
\hline Metaboliszable energy $^{4}(\mathrm{Mcal} / \mathrm{kg})$ & 2.63 \\
\hline Crude protein $(\%)$ & 17.00 \\
\hline Calcium $(\%)$ & 3.50 \\
\hline Available phosphorus (\%) & 0.40 \\
\hline Lysine (\%) & 0.85 \\
\hline Methionine (\%) & 0.40 \\
\hline Methionine+cystine (\%) & 0.69 \\
\hline Threonine $(\%)$ & 0.66 \\
\hline Tryptophan (\%) & 0.19 \\
\hline
\end{tabular}

${ }^{1} \mathrm{CP}$ concentration of SBM was $44.94 \%$.

${ }^{2}$ Vitamin premix provided per kilogram of diet: vitamin A, 12,500 IU; vitamin $\mathrm{D}_{3}, 2,500 \mathrm{IU}$; vitamin $\mathrm{E}, 30 \mathrm{IU}$; vitamin $\mathrm{K}_{3}, 2.65 \mathrm{mg}$; vitamin $\mathrm{B}_{1}$, $2 \mathrm{mg}$; vitamin $\mathrm{B}_{2}, 6 \mathrm{mg}$; vitamin $\mathrm{B}_{12}, 0.025 \mathrm{mg}$; biotin, $0.0325 \mathrm{mg}$; folic acid, $1.25 \mathrm{mg}$; pantothenic acid, $12 \mathrm{mg}$; niacin, $50 \mathrm{mg}$.

${ }^{3}$ Trace mineral premix provided per kilogram of diet: $\mathrm{Mn}$ (from $\mathrm{MnSO}_{4} \cdot \mathrm{H}_{2} \mathrm{O}$ ), $100 \mathrm{mg}$; $\mathrm{Fe}$ (from $\mathrm{FeSO}_{4} \cdot 7 \mathrm{H}_{2} \mathrm{O}$ ), $80 \mathrm{mg}$; $\mathrm{Zn}$ (from $\mathrm{ZnSO}_{4} \cdot 7 \mathrm{H}_{2} \mathrm{O}$ ), $75 \mathrm{mg} ; \mathrm{Cu}$ (from $\mathrm{CuSO}_{4} 5 \mathrm{H}_{2} \mathrm{O}$ ), $8 \mathrm{mg}$; I (from $\mathrm{Ca}\left(\mathrm{IO}_{3}\right)_{2} \mathrm{H}_{2} \mathrm{O}$ ), $0.35 \mathrm{mg}$; $\mathrm{Se}$ (from organic selenium), $0.15 \mathrm{mg}$.

${ }^{4}$ Calculated value. 
Temperature in the respiration chambers was set at $20 \pm 1^{\circ} \mathrm{C}$. Relative humidity was $70 \%$.

One replicate of 36 hens was kept in one of the two respiration chambers for $7 \mathrm{~d}$ periods. In the respiration chambers, hens were fed an experimental diet daily at 08 : 00 from d 1 to 4 , during which the lighting cycle was $16 \mathrm{~h}$ light: $8 \mathrm{~h}$ dark, lighting was switched on and off at 08:00 and 24:00. Free access to water was allowed from nipple drinkers at all times. The first day served as adjustment to the new environment and was not considered in the final calculations. Measurements of $\mathrm{O}_{2}$ consumption and production of $\mathrm{CO}_{2}$ were made on $\mathrm{d} 2$ to 4 in hens under the fed-state. On d 5 to $7, \mathrm{O}_{2}$ consumption and $\mathrm{CO}_{2}$ production were measured in fasting hens without lighting. Hens were weighed before assigning to chambers and at the start and end of measuring fasting HP. Changes in gas concentrations by measuring $\mathrm{O}_{2}$ consumption and $\mathrm{CO}_{2}$ production were recorded at three minutes intervals and, combined with physical aspects of gas exchanges (changes in atmospheric pressure, relative humidity, gas extraction rates), were used to calculate daily total HP (van Milgen et al., 1997).

Heat production in hens was calculated without correction for $\mathrm{N}$ retention (Spratt et al., 1990) according to the equation proposed by Brouwer (1957): $\mathrm{HP}=16.18 \times \mathrm{V}_{\mathrm{O} 2}$ $+5.02 \times \mathrm{V}_{\mathrm{CO} 2}$, where $\mathrm{V}_{\mathrm{O} 2}$ and $\mathrm{V}_{\mathrm{CO} 2}$ are volumes of gas. Since hens were fed diets daily by opening the door of chambers at 08:00, the unstable data from 08:00 to 09:00 was deleted, and the daily total HP was calculated by extrapolation of the actual measurement made during approximately $23 \mathrm{~h}$ to a $24 \mathrm{~h}$ period. The respiration quotient (RQ) was determined as the volume of $\mathrm{CO}_{2}$ produced, divided by the volume of $\mathrm{O}_{2}$ consumed.

Excreta were collected daily from three-adjoining cages on $\mathrm{d} 2$ to 4 , pooled and frozen so that there were four samples per replicate. Samples of experimental diets and excreta (free of feathers, scales, and cracked eggs) were dried in a forced-air oven at $65^{\circ} \mathrm{C}$ to constant weight and then ground to a consistent particle size for subsequent measurement of total $\mathrm{N}$ and GE, measured using a Kjeldahl apparatus (KDY-9380, Shanghai, China) and an oxygen bomb calorimeter (WZR-I A, Changsha, China), respectively. Retained nitrogen (RN) was calculated on a daily basis as the difference between $\mathrm{N}$ intake and $\mathrm{N}$ in the excreta. A sample of each diet was collected and its DM content was measured for DM intake determination. The AME values of experimental diets were calculated by subtracting GE excreted from GE intake and dividing this value by DM intake, whereas diet AMEn values were corrected to zero $\mathrm{N}$ retention using a value of $8.22 \mathrm{kcal} / \mathrm{g}$ of $\mathrm{N}$ retained (Hill and Anderson, 1958).

Retained energy (RE) was defined on a daily basis as the difference between AME intake (MEI) and HP of feeding. Since FHP in laying hens is likely to be less affected by activity under dark condition, the equilibrium FHP may provide an estimate of NEm. Dietary HI was calculated as the difference between HP of feeding and equilibrium FHP. According to Noblet et al. (1994a), NE intake of diets was calculated as equilibrium FHP plus RE. Results concerning MEI, HP, RN, RE, HI, and FHP were expressed as $\mathrm{kcal} / \mathrm{kg} \mathrm{BW}^{0.75}$ per $\mathrm{d}$. The final dietary AME, AMEn and NE contents were expressed as megacalories per kilogram of DM intake (Mcal/kg DM) and correspond to the mean measurements carried out in the four replicates.

Values for AME, AMEn and NE of the test ingredients were calculated according to the difference method (Noblet et al., 1994b):

$$
\begin{aligned}
& \mathrm{AME}=\left[\left(\mathrm{AME}_{\text {test diet }}-\mathrm{AME}_{\text {basal diet }} \times\left(1-\mathrm{C}_{\text {test }}\right)\right] / \mathrm{C}_{\text {test }}\right.
\end{aligned}
$$

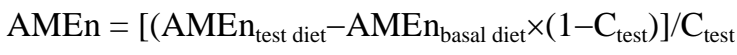

$$
\begin{aligned}
& \mathrm{NE}=\left[\left(\mathrm{NE}_{\text {test diet }}-\mathrm{NE}_{\text {basal diet }} \times\left(1-\mathrm{C}_{\text {test }}\right)\right] / \mathrm{C}_{\text {test }}\right.
\end{aligned}
$$

Where $A M E_{\text {test diet }}$ and $\mathrm{NE}_{\text {test diet }}$ are the $\mathrm{AME}$ and $\mathrm{NE}$ values of experimental diets; $\mathrm{C}_{\text {test }}$ is the substitution ratio of test ingredients.

\section{Statistical analysis}

The data of FHP and RQ during the fasting period were analyzed by two-way ANOVA using GLM (Univariate) procedure of SPSS 17.0 for the interactive effects of diets and fasting time. Duncan's multiple-range test was used to separate means that significantly differed at $\mathrm{p}<0.05$. All the other data except the data of FHP and RQ were analyzed by one-way ANOVA of SPSS 17.0. The significance of differences among four treatment means was evaluated by least significant difference (LSD) post-hoc multiple comparisons test. Significance was $\mathrm{p}<0.05$ and tendency was $0.05<\mathrm{p}<0.1$ unless otherwise stated.

\section{RESULTS}

\section{General observations}

Throughout the experiments, no apparent animal health or technical problems were observed in the laying hens. As shown in Table 3, during d 2 to 4 in the respiration chambers, the feed intake of hens fed with DBD was significantly greater than those of the other three treatments $(p<0.05)$. However, no difference was found among the other three dietary treatments. The RN in hens fed with BD and DBD was higher than that for the WBD and CBD treatments $(p<0.05)$.

\section{Components of energy expenditure}

The energy balance was measured during $\mathrm{d} 2$ to 4 in the respiration chambers. As shown in Table 3, compared with 
Table 3. Utilization of energy in laying hens fed with the experimental diets

\begin{tabular}{|c|c|c|c|c|c|c|}
\hline \multirow{2}{*}{ Item } & \multicolumn{4}{|c|}{ Diets $^{2}$} & \multirow{2}{*}{ SEM } & \multirow{2}{*}{$\mathrm{p}$-value } \\
\hline & $\mathrm{BD}$ & CBD & DBD & WBD & & \\
\hline Average $\mathrm{BW}^{1}(\mathrm{~kg})$ & 1.07 & 1.08 & 1.06 & 1.07 & 0.009 & 0.906 \\
\hline Feed intake (g DM/kg BW ${ }^{0.75}$ per d) & $70.74^{\mathrm{b}}$ & $70.53^{\mathrm{b}}$ & $79.74^{\mathrm{a}}$ & $67.70^{\mathrm{b}}$ & 1.230 & $<0.001$ \\
\hline $\mathrm{RN}^{1}\left(\mathrm{~g} / \mathrm{kg} \mathrm{BW} \mathrm{W}^{0.75}\right.$ per $\left.\mathrm{d}\right)$ & $1.02^{\mathrm{a}}$ & $0.50^{\mathrm{c}}$ & $1.13^{\mathrm{a}}$ & $0.85^{\mathrm{b}}$ & 0.059 & $<0.001$ \\
\hline \multicolumn{7}{|l|}{ Energy balance (kcal/kg BW ${ }^{0.75}$ per d) } \\
\hline $\mathrm{MEI}^{1}$ & $206.28^{\mathrm{b}}$ & $223.98^{\mathrm{a}}$ & $235.56^{\mathrm{a}}$ & $186.62^{\mathrm{c}}$ & 4.367 & $<0.001$ \\
\hline $\mathrm{RE}^{1}$ & $58.87^{\mathrm{b}}$ & $74.89^{\mathrm{a}}$ & $77.12^{\mathrm{a}}$ & $47.12^{\mathrm{c}}$ & 3.495 & $<0.001$ \\
\hline $\mathrm{HP}^{1}$ & $147.41^{\mathrm{b}}$ & $149.08^{\mathrm{b}}$ & $158.40^{\mathrm{a}}$ & $138.51^{\mathrm{c}}$ & 2.166 & 0.002 \\
\hline $\mathrm{HI}^{3}$ & $74.66^{\mathrm{bc}}$ & $79.15^{\mathrm{b}}$ & $88.18^{\mathrm{a}}$ & $70.21^{\mathrm{c}}$ & 1.946 & $<0.001$ \\
\hline RQ (fed state) & $1.02^{\mathrm{a}}$ & $1.02^{\mathrm{a}}$ & $0.96^{\mathrm{b}}$ & $0.94^{\mathrm{b}}$ & 0.010 & $<0.001$ \\
\hline $\mathrm{FHP}^{4}$ & 73.77 & 69.95 & 70.17 & 68.30 & 0.951 & 0.228 \\
\hline \multicolumn{7}{|l|}{ Effect of experimental diets on HI } \\
\hline HI (kcal/kg) & 1.06 & 1.12 & 1.11 & 1.05 & 0.016 & 0.224 \\
\hline HI:MEI (\%) & 36.19 & 35.34 & 37.44 & 37.85 & 0.506 & 0.291 \\
\hline \multicolumn{7}{|l|}{ Energy values and energetic efficiencies } \\
\hline $\operatorname{AME}(\mathrm{Mcal} / \mathrm{kg} \mathrm{DM})$ & $2.92^{\mathrm{b}}$ & $3.18^{\mathrm{a}}$ & $2.95^{\mathrm{b}}$ & $2.76^{\mathrm{c}}$ & 0.033 & $<0.001$ \\
\hline AMEn (Mcal/kg DM) & $2.80^{\mathrm{b}}$ & $3.12^{\mathrm{a}}$ & $2.82^{\mathrm{b}}$ & $2.65^{\mathrm{c}}$ & 0.039 & $<0.001$ \\
\hline $\mathrm{NE}(\mathrm{Mcal} / \mathrm{kg} \mathrm{DM})$ & $1.86^{\mathrm{b}}$ & $2.05^{\mathrm{a}}$ & $1.85^{\mathrm{b}}$ & $1.72^{\mathrm{c}}$ & 0.033 & $<0.001$ \\
\hline NE:AME (\%) & 63.75 & 64.75 & 62.38 & 62.22 & 0.496 & 0.209 \\
\hline
\end{tabular}

$\overline{\mathrm{a}, \mathrm{b}, \mathrm{c}, \mathrm{d}}$ Means $(\mathrm{n}=4)$ within a row lacking a common superscript differ significantly $(\mathrm{p}<0.05)$

${ }^{1} \mathrm{BW}=$ Body weight; RN = Retained nitrogen; MEI = ME intake; RE = Retained energy; HP = Heat production of feeding; RQ = Respiratory quotient.

${ }^{2} \mathrm{BD}=$ Basal diet; $\mathrm{CBD}=$ Basal diet substituted by $50 \%$ of corn; DBD = Basal diet substituted by $20 \%$ of DDGS; WBD = Basal diet substituted by $20 \%$ of wheat bran.

${ }^{3} \mathrm{HI}=$ Hat increment (including HP associated with activity), calculated as the difference between HP of feeding and FHP on the third day of starvation

${ }^{4} \mathrm{FHP}=$ Fasting HP, calculated as the HP on the third day of starvation.

the $\mathrm{BD}$ treatment, the $\mathrm{ME}$ intake and $\mathrm{RE}$ was greater for CBD and DBD groups $(\mathrm{p}<0.05)$ but lower for WBD group $(p<0.05)$. Among the four dietary treatments, hens fed with DBD had the highest HP (Table 3 and Figure 1) and HI, while WBD group had the lowest value $(\mathrm{p}<0.05)$. Hens fed with WBD consumed $186.62 \mathrm{kcal} \mathrm{AME} / \mathrm{kg} \mathrm{BW} \mathrm{BW}^{0.75}$ per d, which occupied about $80 \%$ of ME intake for the DBD treatment $(\mathrm{p}<0.05)$. Both RE and HP in hens increased with ME intake level $(\mathrm{p}<0.05)$ from 47.12 and $138.51 \mathrm{kcal} / \mathrm{kg}$ $\mathrm{BW}^{0.75}$ per $\mathrm{d}$ for the WBD treatment to 77.12 and 158.40 $\mathrm{kcal} / \mathrm{kg} \mathrm{BW}^{0.75}$ per $\mathrm{d}$ for the DBD treatment, respectively.

The HI associated with feeding, expressed as $\mathrm{kcal} / \mathrm{kg}$ $\mathrm{BW}^{0.75}$ per $\mathrm{d}$, accounted for $51 \%$ to $56 \%$ of total $\mathrm{HP}$ and $35.34 \%$ to $37.85 \%$ of MEI among the four dietary

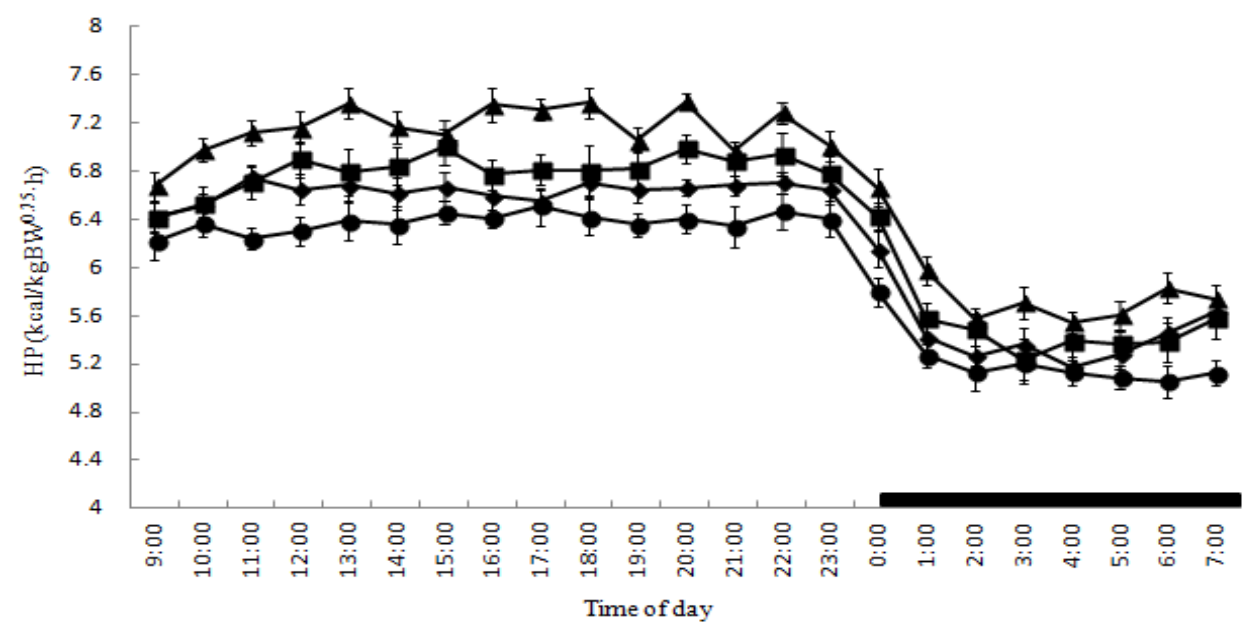

Figure 1. Patterns of variation in the heat production (HP) of hens during feeding period. The continuous line represents mean one-hour HP $(n=4)$ in hens fed with basal diet $(\bullet)$ or a combination of the basal diet with corn $(\boldsymbol{\bullet})$ or DDGS $(\boldsymbol{\Delta})$ or wheat bran $(\bullet)$, respectively. The black horizontal bar indicates the dark period in a day. The HP in hens fed with experimental diets was higher during light period than that without lighting $(\mathrm{p}<0.05)$. 
treatments. However, when expressed as Mcal $/ \mathrm{kg}$ of DM feed intake, there were no significant difference for HI and HI:MEI across treatments.

As shown in Table 3, the highest AME, AMEn and NE values of the four experimental diets was for $\mathrm{CBD}$, while the lowest was for WBD $(\mathrm{p}<0.05)$. No significant differences were found in energy values between the BD and DBD treatments. The efficiency of NE:AME was not influenced by dietary treatment ( $\mathrm{p}>0.05)$.

There was a pronounced diurnal rhythm in HP during feeding (Figure 1). The HP in hens fed with experimental diets was higher during light period than that without lighting $(\mathrm{p}<0.05)$.

\section{$H P$ and $R Q$ in hens during fasting period}

As shown in Table 4, the RQ and FHP in hens was not significantly influenced by the interaction between fasting time and diets ( $p>0.05)$. The RQ in hens on the first day of starvation was higher than that on the second and third days $(p<0.05)$. The FHP decreased over the fasting time $(p<0.05)$.

Experimental diets affected the values of RQ and FHP $(\mathrm{p}<0.05$, Table 4). The RQ in hens fed with WBD was lower than that for $\mathrm{BD}$ and $\mathrm{CBD}$ treatments. The hens fed with BD had the highest FHP, while the DBD and WBD treatments had the lowest value $(p<0.05)$. However, during the third day of starvation, no significant difference was found in FHP ( $p>0.05$, Table 3).

\section{Energy values and utilization efficiencies of the test ingredients}

As shown in Table 5, the AME and AMEn values of the test ingredients were in the order: corn $>$ DDGS $>$ WB ( $p<0.05)$. The net availability of AME of corn tended to be numerically higher than DDGS and WB $(p=0.096)$. The combination of higher $\mathrm{AME}$ and NE/AME ratio resulted in corn having the largest NE value, while WB had the lowest NE value $(\mathrm{p}<0.05)$.

\section{DISCUSSION}

Effect of experimental diets on components of energy expenditure

Compared with the BD group in the present study, low protein content of corn probably lead to the lower $\mathrm{RN}$ in hens fed with CBD, while high protein content of DDGS
Table 4. Effect of experimental diets and fasting time on fasting heat production (FHP) and respiration quotient (RQ) in laying hens

\begin{tabular}{|c|c|c|c|}
\hline Item & $\begin{array}{c}\text { Fasting } \\
\text { time }\end{array}$ & $\mathrm{RQ}^{1}$ & $\begin{array}{c}\mathrm{FHP}^{1} \\
\left(\mathrm{kcal} / \mathrm{kg} \mathrm{BW}^{0.75} \text { per d }\right)\end{array}$ \\
\hline \multirow[t]{3}{*}{$\overline{\mathrm{BD}^{2}}$} & Day 1 & 0.82 & 100.86 \\
\hline & Day 2 & 0.79 & 80.29 \\
\hline & Day 3 & 0.79 & 73.77 \\
\hline \multirow[t]{3}{*}{$\mathrm{CBD}^{2}$} & Day 1 & 0.82 & 99.00 \\
\hline & Day 2 & 0.78 & 77.96 \\
\hline & Day 3 & 0.78 & 69.95 \\
\hline \multirow[t]{3}{*}{$\mathrm{DBD}^{2}$} & Day 1 & 0.80 & 92.05 \\
\hline & Day 2 & 0.78 & 74.55 \\
\hline & Day 3 & 0.78 & 70.17 \\
\hline \multirow[t]{3}{*}{$\mathrm{WBD}^{2}$} & Day 1 & 0.79 & 88.42 \\
\hline & Day 2 & 0.77 & 74.78 \\
\hline & Day 3 & 0.77 & 68.30 \\
\hline Pooled SEM & & 0.002 & 0.427 \\
\hline \multicolumn{4}{|l|}{ Fasting time } \\
\hline Day 1 & & $0.81^{\mathrm{a}}$ & $95.08^{\mathrm{a}}$ \\
\hline Day 2 & & $0.78^{\mathrm{b}}$ & $76.89^{\mathrm{b}}$ \\
\hline Day 3 & & $0.78^{\mathrm{b}}$ & $70.55^{\mathrm{c}}$ \\
\hline \multicolumn{4}{|l|}{ Diets } \\
\hline $\mathrm{BD}$ & & $0.80^{\mathrm{a}}$ & $84.97^{\mathrm{a}}$ \\
\hline CBD & & $0.79^{\mathrm{a}}$ & $82.31^{\mathrm{b}}$ \\
\hline DBD & & $0.79^{\mathrm{ab}}$ & $78.92^{\mathrm{c}}$ \\
\hline WBD & & $0.78^{\mathrm{b}}$ & $77.17^{\mathrm{c}}$ \\
\hline \multicolumn{4}{|l|}{ Source of variation } \\
\hline Fasting time & & $<0.001$ & $<0.001$ \\
\hline Diets & & 0.006 & $<0.001$ \\
\hline Fasting time $\times$ diets & & 0.847 & 0.067 \\
\hline
\end{tabular}

$\overline{\mathrm{a}, \mathrm{b}, \mathrm{c}}$ Means $(\mathrm{n}=4)$ within a column lacking a common superscript differ significantly $(\mathrm{p}<0.05)$

${ }^{1} \mathrm{RQ}=$ Respiratory quotient FHP $=$ Heat production during fasting period. ${ }^{2} \mathrm{BD}=$ Basal diet $\mathrm{CBD}=\mathrm{Basal}$ diet substituted by $50 \%$ of corn; $\mathrm{DBD}=$ Basal diet substituted by $20 \%$ of DDGS; WBD = Basal diet substituted by $20 \%$ of wheat bran.

and more feed intake yielded larger $\mathrm{RN}$ for the DBD treatment. The increase in ME intake was associated with higher RN and RE in the present study, similar results were obtained for growing broilers (Macleod, 1990). However, the RQ under the fed-state did not increase with the ME intake, which was different from the results with turkeys (Macleod et al., 1985). The RE contained both body energy and egg energy. The WBD group had the lowest RQ, indicating that little body energy was used for egg

Table 5. Energy values and energetic efficiencies of corn, dried distillers grains with solubles (DDGS) and wheat bran (WB)

\begin{tabular}{lccccc}
\hline Item & Corn & DDGS & WB & SEM & p-value \\
\hline AME (Mcal/kg DM) & $3.46^{\mathrm{a}}$ & $3.11^{\mathrm{b}}$ & $2.14^{\mathrm{c}}$ & 0.198 & $<0.001$ \\
AMEn (Mcal/kg DM) & $3.44^{\mathrm{a}}$ & $2.79^{\mathrm{b}}$ & $2.10^{\mathrm{c}}$ & 0.199 & $<0.001$ \\
NE (Mcal/kg DM) & $2.25^{\mathrm{a}}$ & $1.80^{\mathrm{b}}$ & $1.14^{\mathrm{c}}$ & 0.145 & $<0.001$ \\
NE: AME (\%) & 65.25 & 57.92 & 53.12 & 2.196 & 0.096 \\
\hline
\end{tabular}

\footnotetext{
$\overline{\mathrm{a}, \mathrm{b}, \mathrm{c}}$ Means $(\mathrm{n}=4)$ within a row lacking a common superscript differ significantly $(\mathrm{p}<0.05)$.
} 
production (Spratt et al., 1990).

Across treatments, HI (including HP associated with activity) contributed $51 \%-56 \%$ to total $\mathrm{HP}$ in hens, and the variability between ME intakes may be the cause of the discrepancies (Latshaw and Moritz, 2009). Additionally, Shannon and Brown (1969) reported that the HI of feeding could also be affected by the chemical composition of feedstuffs as proteins and carbohydrates produce more $\mathrm{HI}$ than fat. For the three test ingredients, the $\mathrm{CP}$ and $\mathrm{EE}$ contents was lowest for corn while highest for DDGS. Dietary composition did not influence the HI when expressed as $\mathrm{kcal} / \mathrm{kg}$ in the present study, which might be due to the different $\mathrm{CP}$ and $\mathrm{EE}$ contents. HI varied between $35.3 \%$ and $37.9 \%$ of $\mathrm{ME}$ intake, suggesting that dietary treatment exerted little influence on the efficiency of deriving available energy from ME intake, which then led to increased dietary NE values with their AME values in the present study.

\section{Effect of light on HP}

A pronounced diurnal rhythm in HP during feeding was observed. The increased HP during light period in the present study agreed with the findings of Sarmiento-Franco et al. (2000) and Li et al. (1992) reported that HP declined with decreasing light intensity in laying hens, which was considered to result from changes in physical activity. Considering that light may stimulate physical activity for laying hens, the same feedstuff may have different NE values at different physiological stages due to the change of lighting cycle.

\section{Effects of experimental diets on HP and RQ during fasting period}

It is difficult to assess how long laying hens should be fasted before FHP will not be influenced by previous ME intake levels. Li et al. (1991) found that HP in laying hens after $46 \mathrm{~h}$ of starvation did not differ from that after $22 \mathrm{~h}$ of fasting. It was suggested that the HP associated with feeding had disappeared after $22 \mathrm{~h}$ of diet deprivation, but the present findings failed to observe an equilibrium FHP on the first and second days, and it was likely that the HP from dietary nutrient metabolism had not disappeared in such a short time. As the fasting time prolonged, the FHP on the third day did not make a marked difference, and the RQ dropped to 0.78 , which indicated that hens mobilized more body fat to sustain energy metabolism (Macleod et al., 1985). It was considered that the HP associated with feeding had not been eliminated until two days of fast. Accordingly, an equilibrium FHP could be obtained on the third day of starvation for laying hens.

The equilibrium FHP, as measured in the present study was about $70.55 \mathrm{kcal} / \mathrm{kg} \mathrm{BW}^{0.75}$ per d, is frequently used to estimate activity-free NEm that is best expressed as energy needs at tissue level to support basic functions under a nonproducing status (Birkett and de Lange, 2001a, b). Similar results (71.16 and $72.69 \mathrm{kcal} / \mathrm{kg} \mathrm{BW}^{0.75}$ per d) were found in hens fed with two different amounts of energy (166.63 and $197.20 \mathrm{kcal} / \mathrm{kg} \mathrm{BW}^{0.75}$ per d) (Ning et al., 2013). O'Neill and Jackson (1974) reported FHP varied from 96.5 to $110.8 \mathrm{kcal} / \mathrm{kg} \mathrm{BW}^{0.75}$ per $\mathrm{d}$ for White Leghorn hens in different physiological stages, which was higher than our findings. They pointed out that the different value of FHP may be influenced by physiological stage and gender. Sakomura et al. (2005) used the comparative slaughter technique to estimate the NEm for Lohmann hens, and found that NEm $\left(79.9 \mathrm{kcal} / \mathrm{kg} \mathrm{BW}{ }^{0.75}\right.$ per d at $\left.22^{\circ} \mathrm{C}\right)$ decreased with rising of ambient temperature. In addition to the above factors such as ambient temperature and genotype, experimental methodologies and variability between hens may also cause these discrepancies in the estimation of FHP or NEm.

\section{Energy values and net availability of AME of test ingredients}

The effect of genotype (meat-type or egg-type) may influence the AME digestibility of feedstuffs (Pishnamazi et al., 2005). The resulting AME value of DDGS was higher than the findings of $2.80 \mathrm{Mcal} / \mathrm{kg} \mathrm{DM}$ for broilers based on the regression method (Adeola and Zhai, 2012), but small differences were found for AMEn values (2.79 vs 2.69 $\mathrm{Mcal} / \mathrm{kg} \mathrm{DM}$ ). The estimated ME values of corn and WB for laying hens in the present study are within the small range of estimates of ME values for chickens of different genotypes, for example, $3.37 \mathrm{Mcal} / \mathrm{kg}$ DM for AMEn value of corn in White Leghorn birds (Pishnamazi et al., 2005) and $1.93 \mathrm{Mcal} / \mathrm{kg} \mathrm{DM}$ for true ME value of WB in ISA Brown laying hens (Mathlouthi et al., 2002). In addition, the experimental methodology may also cause differences on estimation of energy values. Higher NE values (2.74 and $1.24 \mathrm{Mcal} / \mathrm{kg} \mathrm{DM}$ ) were obtained for corn and WB in the comparative slaughter technique (Zhang et al., 2011). Furthermore, the proportion of test feedstuffs contributes to a large variation in estimates of their AME or NE values when using the method of substitution (Wang et al., 2010a). The method of substitution assumes the absence of interactions between the test feedstuff and other dietary components, and potential synergistic or antagonistic effects could be attributed to the test feedstuffs.

Based on the differences in net availability of AME, the energy values of DDGS and WB may be overestimated compared with corn when expressed on AME basis. The net availability of AME of corn in the present study was 7.3\% and $12.1 \%$ greater than that of DDGS and WB, respectively, which can probably be explained by the different chemical compositions of the test ingredients. The $\mathrm{CP}$ and $\mathrm{EE}$ contents of test ingredients were in the order: 
DDGS $>$ WB $>$ corn. Musharaf and Latshaw (1999) reviewed that the $\mathrm{HI}$ is much larger when protein is used as energy source than carbohydrate or fat. Some reports have indicated some improvements from lowering the dietary protein content, such as decreasing the HP (Macleod, 1991) and improving energy efficiencies (Sugahara and Kubo, 1992; Sarmiento-Franco et al., 2000).

The resulting variation in NE/AME ratio of test ingredients could also be due to the differences between their ADF and NDF contents, which were highest in WB while lowest in corn. Noblet et al. (1994a) indicated that the $\mathrm{NE} / \mathrm{ME}$ ratio in pigs varied greatly with the chemical composition of diets and nutrient, the NE/ME ratio for dietary fiber was $58 \%$, which was lower than that for fat $(90 \%)$ and starch $(82 \%)$. Carre et al. (1984) showed that NDF and ADF were detrimental to energy utilization for poultry diets. The physicochemical properties of dietary fiber may increase the energy costs due to a greater energy expenditure on intestinal peristalsis and increased bulk of digest attributable to the fiber, mainly from ADF (Jorgensen et al., 1996). Cellulose and lignin as the main constituents of ADF are water-insoluble to some extent and consequently are known to depress nutrients digestibility.

\section{CONCLUSIONS}

In conclusion, from a methodological point of view, the combination of the indirect calorimetry technique and the difference method for estimating NE values of feed ingredients from complex diets in laying hens, has shown that lighting schedules and fasting time could influence the accuracy of estimation on dietary NE. The closest estimation of the "true" bio-effective energy value of feed ingredients could be obtained with NE system, while the ME system overestimated the protein- and fiber-rich DDGS and wheat bran compared with corn in laying hens.

\section{ACKNOWLEDGEMENTS}

We wish to thank Professor Xiaoming Zhang, Meng Li, and Xiaojie Ma at the Ruminant Metabolism Research Unit in China Agricultural University for their excellent technical assistance in this experiment.

\section{REFERENCES}

AOAC. 1990. Official methods of analysis. 15th ed. Association of Official Analytical Chemists, Arlington, Virginia.

Adeola, O. and H. Zhai. 2012. Metabolizable energy value of dried corn distillers grains and corn distillers grains with solubles for 6-week-old broiler chickens. Poult. Sci. 91:712-718.

Birkett, S. and K. de Lange. 2001a. A computational framework for a nutrient flow representation of energy utilization by growing monogastric animals. Br. J. Nutr. 86:661-674.
Birkett, S. and K. de Lange. 2001b. Limitations of conventional models and a conceptual framework for a nutrient flow representation of energy utilization by animals. Br. J. Nutr. 86:647-659.

Brouwer, E. 1957. On simple formulae for calculating the heat expenditure and the quantities of carbohydrate and fat oxidized in metabolism of men and animals from gaseous exchange (oxygen intake and carbonic acid output) and urine-N. Acta Physiol. Pharmacol. Neerl. 6:795-802.

Carre, B., B. Prevotel, and B. Leclercq. 1984. Cell wall content as a predictor of metabolisable energy value of poultry feedingstuffs. Br. Poult. Sci. 25:561-572.

Jorgensen, H., X. Q. Zhao, K. E. Knudsen, and B. O. Eggum. 1996. The influence of dietary fibre source and level on the development of the gastrointestinal tract, digestibility and energy metabolism in broiler chickens. Br. J. Nutr. 75:379-395.

Hill, F. W. and D. L. Anderson. 1958. Comparison of metabolizable energy and productive energy determinations with growing chicks. J. Nutr. 64:587-603.

Latshaw, J. D. and J. S. Moritz. 2009. The partitioning of metabolizable energy by broiler chickens. Poult. Sci. 88:98105.

Li, Y., T. Ito, M. Nishibori, and S. Yamamoto. 1992. Effects of environmental temperature on heat production associated with food intake and on abdominal temperature in laying hens. Br. Poult. Sci. 33:113-122.

Li, Y. Z., T. Ito, and S. Yamamoto. 1991. Use of limited daily access to food in measuring the heat production associated with food intake in laying hens. Br. Poult. Sci. 32:829-839.

MacLeod, M. G. 1990. Energy and nitrogen intake, expenditure and retention at 20 degrees in growing fowl given diets with a wide range of energy and protein contents. Br. J. Nutr. 64:625637.

MacLeod, M. G. 1991. Fat deposition and heat production as responses to surplus dietary energy in fowls given a wide range of metabolisable energy:protein ratios. Br. Poult. Sci. 32:1097-1108.

MacLeod, M. G., H. Lundy, and T. R. Jewitt. 1985. Heat production by the mature male turkey (Meleagris gallopavo): preliminary measurements in an automated, indirect, opencircuit multi-calorimeter system. Br. Poult. Sci. 26:325-333.

Mathlouthi, N., M. Larbier, M. A. Mohamed, and M. Lessire. 2002. Performance of laying hens fed wheat, wheat-barley or wheatbarley-wheat bran based diets supplemented with xylanase. Can. J. Anim. Sci. 82:193-199.

Musharaf, N. A. and J. D. Latshaw. 1999. Heat increment as affected by protein and amino acid nutrition. World Poult. Sci. 55:233-240.

Ning, D., Y. M. Guo, Y. W. Wang, and Y. Z. Peng. 2013. Earlier metabolizable energy intake level influences heat production during the following 3-day fast in laying hens. Asian-Aust. J. Anim. Sci. 26:558-563.

Noblet, J., H. Fortune, X. S. Shi, and S. Dubois. 1994a. Prediction of net energy value of feeds for growing pigs. J. Anim. Sci. 72:344-354.

Noblet, J., X. S. Shi, and S. Dubois. 1994b. Effect of body weight on net energy value of feeds for growing pigs. J. Anim. Sci. 72:648-657.

National Research Council (NRC). 1994. Committee on animal 
nutrition. Subcommittee on Poultry Nutrition. Nutrient Requirements of Poultry. 9th rev. ed. National Academy of Sciences, Washington, DC.

O'Neill, S. J. B. and N. Jackson. 1974. The heat production of hens and cockerels maintained for an extended period of time at a constant environmental temperature of $23^{\circ} \mathrm{C}$. J. Agric. Sci. 82:549-552.

Pishnamazi, A., J. Pourreza, M. A. Edriss, and A. H. Samie. 2005. Influence of broiler breeder and laying hen breed on the apparent metabolizable energy of selected feed ingredients. Int. J. Poult. Sci. 4:163-166.

Sakomura, N. K., R. Basaglia, C. M. L. Sá-Fortes, and J. B. K. Fernandes. 2005. Model for metabolizable energy requirements of laying hens. R. Bras. Zootec. 34:575-583.

Sarmiento-Franco, L., M. G. Macleod, and J. M. Mcnab. 2000. True metabolisable energy, heat increment and net energy values of two high fibre foodstuffs in cockerels. Br. Poult. Sci. 41:625-629.

Shannon, D. W. and W. O. Brown. 1969. Losses of energy and nitrogen on drying poultry excreta. Poult. Sci. 48:41-43.

Spratt, R. S., H. S. Bayley, B. W. McBride, and S. Leeson. 1990. Energy metabolism of broiler breeder hens. 1. The partition of dietary energy intake. Poult. Sci. 69:1339-1347.
Sugahara, K. and T. Kubo. 1992. Involvement of food intake in the decreased energy retention associated with single deficiencies of lysine and sulphur-containing amino acids in growing chicks. Br. Poult. Sci. 33:805-814.

van Soest, P. J. and R. H. Wine. 1967. Use of detergents in the analysis of fibrous feeds. I. Preparation of fibre residues of low nitrogen content.VI.Determination of cell-wall constituents. J. Assoc. Offic. Anal. Chem. 50:50-55.

van Milgen, J., J. Noblet, S. Dubois, and J. F. Bernier. 1997. Dynamic aspects of oxygen consumption and carbon dioxide production in swine. Br. J. Nutr. 78:397-410.

Wang, X., G. Jia, X. Li, and K. N. Wang. 2010a. Determination of the net energy and appropriate substitution ratio of soybean meal yellow-feathered broilers for using a substitution method. Chinese J. Anim. Nutr. 22:1434-1439.

Wang X. L., G. M. Zhang, J. Q. Wang, and E. P. Zhang. 2010 b. Measurement on net energy value of corn and soybean meal for laying hens. J. Northwest A \& F University - Nat. Sci. Ed. 38:71-76.

Zhang, Q. L., G. Jia, X. Q. Wu, and K. N. Wang. 2011. Determination of the net energy values of feedstuffs and its influence on performance and nitrogen availability of yellowfeather broilers aged from 1 to 21 days. Chinese J. Anim. Nutr. 23:1094-1100. 